\title{
THE IMPORTANCE OF ENERGY FOR THE ECONOMY, SUSTAINABLE DEVELOPMENT AND ENVIRONMENTAL PROTECTION - AN ECONOMIC ASPECT
}

\author{
Ljiljana Stošić Mihajlović, ${ }^{1}$ Svetlana Trajković ${ }^{2}$ \\ ${ }^{1,2}$ High School of Applied Professional Studies, Vranje, Republic of Serbia \\ mihajlovicp@ptt.rs
}

\section{Original Scientific Paper doi:10.5937/jouproman6-16221}

\begin{abstract}
In the area of modern economy and environmental protection there are no significant changes: the old problems are not solved, and the existing ones are deepening. Humanity is still struggling with three existential problems: lack of food, lack of drinking water and insufficiently energized energy. They are also associated with the dangers of further degradation of the environment, the general fear and fear of terrorism and wars, the emergence of diseases for which modern medicine simply has no solution and which threatens to overcome the challenge of pandemic. Energy is still a mood of economic development, with at the same time a disastrous effect on the environment, when traditional sources of fossil resources are used as sources of energy. The paper explores the phenomenon of the impact of energy on the sustainable development of the economy, with a key focus on environmental protection, as well as the possibilities for adaptation to mitigate the consequences of this global phenomenon. In this regard, special attention has been devoted to researching the role and significance of energy from renewable sources as a possible response to current or expected climate stimuli or their consequences in natural and humanism systems. Particular emphasis is placed on the principle of adaptation, which includes mitigation of damages or the exploitation of effective opportunities; understanding how climate can change, what can be impacts, and capacity building and action on these impacts.
\end{abstract}

Key words: energy, sustainable development, environmental protection.

\section{Introduction}

The biggest task of today with which mankind will fight for the next 50 years is solving problems related to energy, water, food, endangered environment, poverty, terrorism and wars, diseases, education, democracy, population (2003 - 6.3 billion, estimates $2050-9-10$ billion).
The growth of the world's population is conditioned by the growth of the energy demand, which, alas, today, predominantly products from fossil sources: coal, oil and gas. By 2020, global energy demand is expected to exceed the current demand by as much as $50 \%$ ! (Stošić Mihajlović, Lj 2015, page 18) In addition, limited reserves of fossil fuels, increase in research costs and climate threats from greenhouse gases and $\mathrm{CO} 2$, is imposed as a global limitation. It is noteworthy that in the next 50 years energy will be the main problem facing all countries in the world, especially the poor countries, which strive for accelerated economic prosperity, which means opening up new production capacities and new investments, require a higher amount of energy that can not be satisfied from domestic sources.

\section{Klimate as a resource}

Climate is a basic natural resource, from which depends the energy potential of every cabbage and therefore has a dominant influence on ecosystems, as well as on the state and development of society and human civilization in general.

According to the Global Climate Change Impact Assessment (IPCC, 2007 and EEA, 2008), the areas of Central and Eastern Europe will be characterized by: more temperature extremes, less precipitation during the summer, more river floods during winter, higher water temperatures, variability in the yield of cereals, a greater risk of forest fires and a lower stability of forest ecosystems. 
Research and scenarios of global climate change indicate the likelihood of more frequent occurrences of storms, extreme heat, increased risk of extinction of species, etc. (IPCC 2007).

Climate change on the Earth and the ecological crisis have resulted from uncontrolled economic, primarily industrial development, inefficient technologies and excessive use of fossil fuels. Pollution of the atmosphere by the gases caused by the so- the "greenhouse effect", the destruction of the ozone layer that protects the earth's living world from excessive radiation, global warming, are all the problems that threaten today's generations, and if such a trend continues, it will endanger the future. Scientific reports emphasize that adaptation to these effects will require a good knowledge of socio-economic and natural systems, their vulnerability and vulnerability to climate change, as well as their own adaptation capacity.

A major global problem is the chronic energy crisis. Fossil fuel reserves (detected and assumed) are limited and according to forecasts, depending on the type of energy and consumption, it is possible that most will disappear by the middle of this century, when global economic collapse could occur. Adding to this the envisaged climate change, it creates an environment for many dramatic consequences, including frequent droughts, lack of drinking water, reduction of agricultural production, the onset of endemic hunger among the poor layers of the population, the occurrence of epidemics, migration of the population in search of water and food, conflicts around limited resources, etc. (Nikolić, 2010). Climate change is a global problem, but the consequences will be felt and be of interest at both the regional and local levels. Estimates are that these changes will have significant implications for urban areas, given that over $50 \%$ of the world's population and $80 \%$ of Europe's population today live in cities, such problems become the cause of increasing interest.

The World Wildlife Fund (WWF, 2005), more than a decade ago, drew attention to the significant warming of the capital cities across Europe. Bearing this in mind, strategic projects are being launched in many countries, such as the "Adaptation Strategies for Climate Change in the Urban Environment -ASCCUE" project. in the United Kingdom. These projects include preparation for climate change through strategic planning and the conduct of wise ecological, economic and energy policies. An important aspect of this project is to explore the potential of renewable energy resources in adapting to climate change. The degree of exploitation of conventional natural resources, primarily coal and oil, as a source of energy enters the stage when one has to think about their expansion and diversity, in order to adequately respond to the increasing needs of mankind for energy. This equally applies to the problem of population growth, the need for food and water, and civilization progress. Solving these problems is not possible without energy, as an important factor of development. Classical sources in the future will not be able to resolve all these needs unambiguously. Due to the multiple problems caused by the energy crisis, most countries of the world have been obligated by different conventions and declarations that part of the classical energy sources, depending on the possibilities, will be replaced with renewable energy sources (RES).

With the development of ecological awareness, the use of RES in the world takes on significant conditions. In addition to preventing gas emissions, renewable energy can provide energy independence. One of the important tasks of using renewable energy is to enable local consumers greater energy independence and independence, primarily from imports, and then from national and regional energy supplies through large distribution systems. 
Consequently, at the state level, the countries of the world have committed themselves to alter existing strategies for using energy sources in the direction of greater use of renewable sources through strategies, plans and legislation. "The global economic crisis in a relatively short period of time has led, however, a dramatic fall in the stock market, bringing down share prices and companies which are economic parameters resisted the crisis, but could not resist the psychology of mass spreading panic and fear of investors. It is also shown, and all the multidisciplinary nature of financial markets whose understanding is all the more important to know the theory of the behavior of market participants." 7

\section{The importance of energy for sustainable development from the economic theory}

From the time of Adam Smith and classical economic thought, country, labor and capital, they are considered the main factors of production and the main sources of economic growth. In time, these factors have been added by the organization as the fourth factor, while in recent times added knowledge or intellectual capital. During the development of economic thought and in economic doctrines, the direct and explicit importance of the role of energy as one of the keys to the factors of economic prosperity was not given. Energy remains present and recognized in economic theory and practice as an intermediate good while, according to still current models of neoclassical economics, economic growth is attributed to technological progress and knowledge. In economic theory, for a long time, the amount of energy available to a given economy was endogenously

\footnotetext{
${ }^{7}$ Ljiljana Stosic Mihajlovic, FUNCTIONING OF FINANCIAL AND CAPITAL MARKETS IN MODERN CONDITIONS, (JPMNT) Journal of Process Management - New Technologies, International Vol. 4, No.4, 2016. pag. 30, www.japmnt.com
}

determined, of course, under the influence of biophysical and economic constraints (Stern and Cleveland, 2004, p. 5). It is certain that some driving force must enable growth factors, such as land, labor, capital, organization, technology and knowledge in each economic sector and in each process of economic activity, to result in the growth of the domestic product. That's just energy. Namely, the process of production (and economic growth as the final resultant) involves the transformation of matter from one form to another, ie the transformation of inputs, ie, raw material in the final product, and this transformation requires energy (Cleveland et al., 1996). Energy enables the continuity and longterm nature of the entire economic activity not only as a supplement to standard production inputs, but without it the economy would not be possible at all.

According to Alam (2006), every business consists of energy flows that are directed towards the production of goods and services. Such a focus on energy creates many new assumptions. Namely, putting energy into the focus of economic activity identifies the use of energy as an important source of economic growth and the inevitable driving force of all economic activities (Stern and Cleveland, 2004). In other words, the economy should be seen as an energy system consisting of energy flows and conversions that culminate precisely in the production of goods and services, and energy as a key source of economic growth, industrialization and urbanization (Imran, 2010, p. 206). According to the ecological economics, energy is the most important primary factor of production (Georgescu-Roegen, 1971, 1975).

The profit conflict, which results from natural resources, often leads to a focus on the distribution of wealth instead of its creation, to social struggles, ie, conflict, undemocratic authority and inequality, that is, corruption, political opportunism and bureaucracy. 
According to Smith (2006, p. 68), developing countries are often less resource-rich than the current developed countries at the time they began their growth. Several developing countries abound in the vast reserves of oil, ore and raw materials that are rising world demand, while many smaller countries (especially in Asia) are poorly abundant in natural resources. On the other hand, in parts of Latin America and Africa (eg Mexico, Nigeria and Venezuela) where natural resources are greater, it is necessary to have a larger, even huge investment of capital for their exploitation, and such financial resources can be obtained by sacrificing a substantial part of the control over natural resources. Models related to the phenomenon of the curse of natural resources are known as the so-called. models of the Dutch disease models, based on the theory that the increase in the available quantity of one factor with an unchanged amount of the second and unchanged technology will lead to a decline in the production of the product that is more intensively used by the production factor whose the available quantity has not changed. In economic theory, the "Dutch disease" is the name for a set of economic consequences that arise with the specialization of the country according to its comparative advantage. (The name was sketched in 1977 in The Economist to describe the decline of the Dutch manufacturing sector following the discovery of natural gas in the country during the 1960s (Ebrahim-Zadeh, 2003).

\section{Ecological economy}

Ecological economics is the term for a "new" or modern economy driven by the concern and interest to solve accumulated global environmental problems. It views the world of nature and society in a very different way from the conventional economy. The ecological economy deals with the review of the excessive use of materials and thermodynamic bases of economic activity, mainly focusing on the inevitable interactions of people and ecosystems in the broadest sense. The ecological economy examines the fundamental relationships between physical and biological systems, the problems of ecosystem management in a sustainable way and the impact of social on ecosystems. It is a link between ecology and economics, and there is also a special and leading scientific discipline of the 21st century, because in the focus of its research exclusively economy and profit, it already observes the co-operation of economic parameters with regard to quality of life. The ecological economy summarizes other scientific disciplines (not only economic and ecological), in fact it leads to the integration of natural and social sciences, among which a clear border must be revised and deleted.

In addition, although natural resources and energy were gaining importance in the neoclassical model of economic growth, this did not satisfy critics of neoclassical growth theory. Namely, Nicholas Georgescu-Roegena was the first to point out the lack of energy in economic theory. Georgescu-Roegen (1971, 1975) pointed out that neoclassical economists abstract natural resources and energy flows, while at the same time ignoring economic residues and waste as a byproduct of economic activity. He found that standard economic theory does not recognize the fact that on one hand energy and material resources are irreversibly spent, while on the other hand the detrimental effects of economic activity on environmental pollution continue to accumulate. Perpetuum mobile economic system is simply not possible. The problem arises from the overly optimistic attitude of economists to the endless growth potential based on the endless use of the natural environment and its capacities. This is due to unrealistic optimism based on a limited view of the world that excludes nature, natural capacities and limitations of energy resources (Alam, 2006, p. 2). 
Contrary to unrealistic economic optimism, members of the ecological economy advocate the idea that the so-called " physical dimension and environmental capacities condition the possible economic production. In contemporary terrors of economic prosperity, economic systems exchange energy and matter with the environment, so that the economic system must accept as an open thermodynamic system.

The eco-economics followers start from the material base in one country and criticize the neoclassical theory because of the failure to locate economic activity within the so-called. physical realities they perceive the economy as a complex system (Ramos-Martin, 2003, p. 7), as an open subsystem of the global ecosystem. The process of economic production consists of inputs of natural capital, but the total economic activity includes the necessary contents of the ecosystems that enable human life. The ecological economy emphasizes the importance of preserving natural capital as an instrument for creating additional, new values (Ayres and Warr, 2009). Namely, the global economic system is dependent on four basic biological systems (forests, fisheries, forests and grasslands).

According to Rifkin (2002, p. 323), basic biological systems do not only allow available food but also all raw materials for industrial production. This approach to the economic system also implies the absorption of waste as a by-product of economic activity and the preservation of the environment that enables the life and survival of civilization.

\section{The influence of energy in sustainable economic development and environment}

The most important strategic documents of the Republic of Serbia (Strategy for the development of enegetics by 2025 with projections until 2030 and the National Strategy for the sustainable use of natural resources and goods) undoubtedly point to the necessity of promoting greater use of renewable energy sources (but the results so far are still unsatisfactory). In the above-mentioned document, it is unambiguously stated: "All analyzes of

key economic and technological changes indicate that in the last two and a half centuries, energy has been the driving force and key factor of economic change, as well as the backbone of economic development. Changes that take place globally require a long-term perspective of their impact on the national level and proper management of energy development. "

According to Directive 2009/28 / EC, "energy from renewable sources is energy from non-fossil renewable sources, such as: wind energy, solar, aerothermal, geothermal, hydrothermal, ocean energy, hydropower, biomass, landfill, gas from waste treatment plant and biogas. "Renewable energy sources and their management is an important issue in all developed countries. "The priority of world development today is the protection of energy supply at affordable prices, but in order to maintain and increase living standards. At the same time, the negative effects of the use of energy on the environment, especially fossil fuels, must be reduced. Therefore, the world from year to year redefines energy policy and focuses on the creation of a competitive energy market through the use of renewable energy sources. "(Mihajlović-Milovanović, Z. 2010, page 59) A good way to point out the significance and impact energy on the economy and the environment by applying a tabular overview. 
Table 1. Comparison of energy impacts from different sources on the economy and the environment

\begin{tabular}{|l|l|l|}
\hline Type of energy resources & Non renewable energy & Renewable energy sources \\
\hline Variables & Easy storage & $\begin{array}{l}\text { In most cases, it is impossible to } \\
\text { store and transport }\end{array}$ \\
\hline Possibility of storage and transport & Easy transport & Not \\
\hline $\begin{array}{l}\text { Consistency } \\
\text { construction of the plant }\end{array}$ & $\begin{array}{l}\text { High units per unit of power There } \\
\text { are no additional costs because } \\
\text { there is no purchase of combustion } \\
\text { fuels }\end{array}$ \\
\hline Plant and maintenance costs & $\begin{array}{l}\text { Lower investments per unit of } \\
\text { power High costs extra for the } \\
\text { purchase of a combustible fuel }\end{array}$ & Low \\
\hline The effect of "greenhouse gases" & High, how life is growing & In most cases, there is no impact \\
\hline Impact on environmental pollution & High & Not \\
\hline $\begin{array}{l}\text { Possibility of fast and balanced } \\
\text { economic development }\end{array}$ & Yes & Yes \\
\hline
\end{tabular}

All types of renewable energy (hydropower, geothermal energy, biomass energy, solar and eolic energy) are inseparable and therefore need to be used to the maximum, on the one hand, because they are renewable, and on the other hand, it is energy that does not generate waste, does not create pollution does not create problems related to clean air, clean environment and clean water, and does not affect sustainable development.

\section{Conclusion}

Energy is fundamental to economic development, but at the same time it must be in the function of preserving the environment. Only this approach to energy leads to a sustainable energy system, a more efficient economy and greater social well-being, with sustainable balances and capacities of natural resources and as low as possible pollution levels.

A new scientific discourse created within the synthesis of social and natural sciences, called the ecological economy, pays due attention to the laws of thermodynamics in the process of economic activity, which ensures economic activity while preserving the environment in a realistic framework of sustainable development.

Energy management is the way to supporting the reduction of environmental threats and economic costs while increasing the quality of life and economic prosperity.

\section{Literature}

1. Georgescu-Roegen, N. (1971.). The Entropy Law and the Economic Process. Harvard University Press

2. Imran, K., Siddiqui, M.M. (2010.): "Energy Consumption and Economic Growth: A Case Study of Three SAARC Countries", European Journal of Social Sciences, 16 (2): 206-213.

3. Internacional Panel for Climate Change IPCC, 2007 i EEA, 2008

4. Mihajlović - Milovanović Zorana (2010): Obnovljivi izvori energije, Megatrend univerzitet Beograd

5. Nikolić, Radovan (2010): Екопоmija prirodnih resursa, Kompjuter centar D.O.O. Bor.

6. Ramos-Martin, J., Ortega-CerdN, M. (2003.). "Non-linear relationship between energy intensity and economic growth", http://www.rrojasdatabank.info/ thermo/PS35p.pdf

7. Rifkin, J. (2002.). Entropija - novi pogled na svijet. Misl, Zagreb

8. Stošić Mihajlović, Ljiljana (2015): Obnovljivi izvori energije, VŠPSS, Vranje 
(JPMNT) Journal of Process Management - New Technologies, International

Vol. 6, No 1, 2018.

9. Stošić Mihajlović, Ljiljana (2016) FUNCTIONING OF FINANCIAL AND CAPITAL MARKETS IN MODERN CONDITIONS, (JPMNT) Journal of Process Management - New Technologies, International Vol. 4, No.4, 2016. pag. 30, www.japmnt.com

10. Strategija razvoja energetike Republike Srbije do 2025. godine sa projekcijama do 2030

11. Stern, D. (2010.). "The Role of Energy in Economic Growth", United States Association for Energy Economics and International Association for Energy Economics, Working Paper No. 10-055, November 2010 , http://ssrn.com/abstract=1715855 (pregledano 16. listopada 2013. godine).
12. Cleveland, C.J. et al. (1996.). "Natural Capital, Human Capital and Sustainable Economic

Growth",http://www.bu.edu/cees/research/ workingp/pdfs/9702.

http://www.ipcc.ch/publications and data /ar4/syr/en/contents.html

13. http://cmpopenstandards.org/guidance/wwfconceptual-models/

14. http://climateadapt.eea.europa.eu/metadata/projects/ada ptation-strategies-for-climate-change-inthe-urban-environment

15. http://eur-lex.europa.eu/legalcontent/EN/ALL/?uri=celex\%3A32009L0 028 